\title{
A ESCURIDÃO NA PENUMBRA DO ABISMO: ESPECTROS DO EXPRESSIONISMO ALEMÃO EM DARK
}

André Bonsanto Stamberg José da Silva Júnior

Recebido em 04 dez 2020. André Bonsanto

Aprovado em 06 mar 2021. Bolsista de Pós-Doutorado (PNPD/CAPES).

Professor colaborador junto ao Programa de PósGraduação em Ciências Sociais e Humanas da Universidade do Estado do Rio Grande do Norte.

http://lattes.cnpq.br/5025469064512821

https://orcid.org/0000-0001-8406-4009

andrebonsanto@gmail.com

Stamberg José da Silva Júnior

Mestrando pelo Programa de Pós-Graduação em Ciências Sociais e Humanas da Universidade do Estado do Rio Grande do Norte. Bolsista CAPES.

http://lattes.cnpq.br/174557579377712

https://orcid.org/0000-0002-8680-6501

stambergjunior@gmail.com

Resumo: O presente artigo analisa elementos do expressionismo alemão nas três temporadas da série de ficção científica Dark (2017, 2019, 2020). Para isso, discutimos algumas características referentes à estética estudada em relação aos aspectos discursivos, imagéticos e narrativos que compõem a mise-enscène e o espaço diegético da série. Os resultados 
apontam para um alinhamento entre os objetos analisados no que se refere a pontos como: o duplo, o espelhamento, o fantástico, a manipulação, a ciência mágica e o limiar das águas obscuras do humano.

Palavras-chave: Expressionismo Alemão. Análise Fílmica. Ficção Científica. Séries. Dark.

Abstract: This paper analyzes elements of the German expressionism in the three seasons of the science fiction series Dark (2017, 2019, 2020). For this, we discuss some characteristics related to the expressionism in relation to the discursive, imagetic and narrative aspects that make up the mise-enscène and the diegetic space of the series. The results aim to an alignment between both of the analyzed objects with regard to aspects such as: the double, the mirroring, the fantastic, the manipulation, the magic science and the threshold of the dark waters of the human.

Keywords: German Expressionism. Film Analysis. Science Fiction. Series. Dark.

\section{INTRODUÇÃO}

Por meio de votação popular promovida pelo site Rotten Tomatoes, Dark foi considerada a melhor produção original da Netflix no ano de 2020, abarcando $80 \%$ dos cerca de 2,5 milhões de votos. A narrativa também ganhou o prêmio Grimme-Pries, o mais importante da televisão alemã; e segue com nota 8,8 no IMDb, instância crítica significativa no universo cinematográfico online $^{1}$. Com um enredo complexo formado por diversos arcos temporais, Dark é uma série de ficção científica que

1 Sobre a votação, consultar: https://entretenimento.uol.com.br/noticias/ redacao/2020/05/05/dark-bate-stranger-things-e-mais-em-eleicao-de-melhor-serieda-netflix.htm Acesso em: 27 nov. 2020. 
envolve mistério, suspense, referências a filósofos, cientistas e pensadores da cultura ocidental.

Ainda que o alcance e o sucesso da narrativa sejam notórios, pouco se tem discutido sobre as múltiplas facetas de objetos de pesquisa que a série possa suscitar no ambiente acadêmico. O pesquisador equatoriano Lenin Paredes (2019), por exemplo, discute a concepção de tempo cíclico do ponto de vista da ficção científica que Dark traz no roteiro. No Brasil, Vargas e Corrêa (2019) demonstram as alterações na estrutura da narrativa televisual que Dark apresenta. Trabucco (2018) mostra a relação que a série faz a partir das releituras de fatos reais, como o desastre de Chernobil.

Estudo recente de nossa autoria, por sua vez, discute a relação de Dark com elementos do mito e da tragédia grega. Visamos, neste artigo, ampliar e contribuir para o debate sobre essa narrativa audiovisual importante no contexto contemporâneo. Nosso foco estará nos traços fílmicos que possam apontar para o vanguardismo expressionista - e seus aspectos sombrios - surgido na Alemanha no início do século XX.

A predileção e o "gosto dos alemães pela morte" (EISNER, 1985, p. 65), que se faz presente em estilos como o romantismo, o gótico e o expressionismo, também encontra-se na atmosfera sorumbática e melancólica da série. Embora tenha características e referências explícitas a filmes hollywoodianos (como Doonie Darko e De volta para o futuro), e esteja inserida em um circuito internacional por estar alocada em um serviço de streaming, Dark contempla a possibilidade de reconhecermos, a partir 
da experiência estética do audiovisual, sensações profundas e avassaladoras, mas nem sempre aprazíveis em nós.

Ao buscarmos estabelecer confluências entre Dark e o expressionismo alemão - localizando elementos da estética vanguardista, como o fantástico e o insólito - estamos, de algum modo, realocando a série dentro de um contexto histórico e nacional que permite compreender tendências intelectuais, artísticas e técnicas que estão articuladas à mentalidade do país a qual pertencem os objetos postos aqui em diálogo. Sabemos que para analisar um filme (ou uma série) precisamos situá-lo num contexto, numa história.

Se considerarmos o cinema como arte, devemos situar o filme em uma história das formas filmicas. "Assim como os romances, as obras pictóricas ou musicais, os filmes inscrevem-se em correntes, em tendências e até em 'escolas' estéticas, ou nelas se inspiram a posteriori" (GOLIOT-LÉTÉ; VANOYE, 2012, p. 21). Esse empreendimento pode ser considerado algo redutor ou utópico, mas ao entendermos que um produto audiovisual nunca é isolado e se conecta mais ou menos a uma tradição "é preciso ser capaz de descobrir as figuras de conteúdo ou de expressão que permitem definir o papel e o lugar da obra nesse movimento ou nessa tradição" (GOLIOT-LÉTÉ; VANOYE, 2012, p. 22).

Estamos conscientes de que nosso trabalho possa estabelecer limitações essencialistas e, possivelmente, generalistas sobre o que viria a ser o cinema alemão, a cultura alemã, entre outros termos que serão utilizados aqui. Sabemos que as identidades ou as identificações se reconfiguram e são forjadas por relações de poder, além de critérios sociais, subjetivos e culturais. No entanto, 
entendemos que há fios que podem ser pesquisados e debatidos ainda que tenham como origem a reiteração de uma identidade nacional construída ao longo dos séculos pelos próprios pensadores daquele país. Embora não seja nosso objetivo discorrer sobre o que seriam os termos supracitados (cinema e cultura alemães), eles perpassarão nosso trabalho referindo-se àquilo que os autores dispostos nas referências entendem por esses termos.

Os ecos do expressionismo, vanguarda que "trata do horror, de personagens fantásticos em périplos aterrorizantes" (MURARI; PINHEIRO, 2012, p. 138) e que transpassa elementos do campo literário ao cinematográfico, por exemplo, transformaram em vetor de influência o modo de fazer cinema e de experienciar a estética audiovisual. Ao realizarmos consonâncias entre certa expressão artística de outrora com uma narrativa atual, entendemos aquela não como um acontecimento distante dos fenômenos contemporâneos, mas como catalisadora que se desdobra em influxo dentro do contexto artístico nacional e internacional. Corroboramos com o pensamento de Goliot-Lété e Vanoye, quando dissertam que "é claro que essas transposições formais sempre se efetuam num contexto diferente. E é exatamente esta a tarefa do analista: encontrar a filiação, a referência, a inspiração, apreciar seu emprego, seus limites, suas novas significações" (2012, p. 32).

Por isso, nas discussões que aqui se seguem, iniciaremos o debate sobre o próprio expressionismo e seus efeitos nas artes de forma extemporânea. Discutiremos, ainda, o expressionismo na tela demoníaca² do cinema alemão clássico, citando cineastas como 
Robert Wiene, Paul Leni, F.W. Murnau, Paul Wegener, Fritz Lang. Em seguida, apresentaremos os principais eixos temáticos desse movimento artístico nos elementos que compõem a série Dark. Objetivamos assim, por meio de uma análise imagética, fílmica, discursiva e narratológica compreender em Dark elementos que permeiam o expressionismo, tais como: o duplo, o espelhamento, o fantástico, a morte, a manipulação, a ciência mágica, e os elementos sombrios presentes na alma humana que são suscitados pela estética presente na narrativa.

\section{SOMBRAS DE UM GRITO ANGUSTIANTE: A VANGUARDA EXPRESSIONISTA}

Marcado pelas teorias que evocaram o irracional, o inconsciente e as dimensões desconhecidas do humano ${ }^{3}$ em relação a ele mesmo, o movimento artístico conhecido como expressionismo tem seu desenrolar no período posterior à Primeira Guerra Mundial. Temas como angústia, o desamparo e as vulnerabilidades do Ser apresentam-se na tessitura dessa forma de criação que se rebela contra as ortodoxias estilísticas submetidas à ordenação racional em detrimento ao impulso e à espontaneidade. Prevalece, aqui, a degeneração, a deformação, o monstruoso, as sombras: aquilo que nos causa horror e aversão; aquilo que vai de encontro à lógica mecanicista que paira sobre a Modernidade.

"que Ihe davam os gregos, e como o entendia Goethe" (1985, p. 13). Sucintamente, entendemos que isso refere-se a uma cisão/divisão na alma humana, cuja interioridade é marcada por uma discordância: zonas de sombra que nos afetam, angustiam e que são ontológicas ao ser.

3 O conceito de vontade como algo cego e não-racional em Schopenhauer (2001); a morte de Deus e a crítica de Nietzsche (2013) acerca da transcendência, dos valores, da razão, além do estímulo do filósofo ao corpo e aos instintos; os estudos sobre o desejo, a libido, os sonhos, o inconsciente e a psique humana em Freud (1996), enfim, são alguns dos exemplos das ideias que trouxe contribuições significativas às artes no século XX. 
O expressionismo constitui-se como uma "prospecção de estados fronteiriços e posições extremas, que frequentemente implicam crises de decisão e gestos hiperbólicos dirigidos simultaneamente em direções contrárias" (CARDINAL, 1984, p. 17). As ressonâncias emocionais são expostas em expressões visivelmente dramáticas - não como representação de um sentimento, mas como uma apresentação direta deste. A necessidade de exprimir-se sem restrições é o ponto nevrálgico do movimento e aponta para uma aura inquietante de emoções manifestas de modo pungente, desvelando uma conturbada alma humana.

As vibrações de sensibilidades densas, como nas últimas pinturas de Van Gogh ou nas expressões artísticas de Edward Munch, por exemplo, nos atravessam como algo que está vivo não só na obra, nem em seu criador, mas sobretudo, em nós mesmos. A precariedade do ser, o abandono e a tortura de viver em um mundo cuja desorientação parece absoluta são transpostas em arte, ecoando o mal-estar de um grito mudo e perene que distorce e contorce a aparência do real.

O expressionismo pode ser considerado uma visão de mundo compartilhada a partir de seus predecessores artísticofilosóficos como o romantismo, o gótico e o barroco. "Mesmo diferentes em muitos aspectos, essas manifestações tinham em comum a atenção voltada à dimensão subjetiva e espiritual diante de um mundo aterrorizador" (KOHATSU, 2013, p. 104). A vanguarda aqui estudada, porém, diferencia-se pelo uso de imagens assustadoras e fantasmagóricas em um cenário desolador: "o que era sonho no Romantismo torna-se pesadelo 
no Expressionismo" (RIBEIRO, 1964, s.p). Segundo Roger Cardinal (1984):

Apaixonado e premente, o impulso criativo da arte expressionista origina-se de um compromisso com o primado da verdade individual, pois encara a subjetividade como comprovação daquilo que é mais real. Esse compromisso é o dogma central de uma corrente de pensamento filosófico e psicológico que, originária do romantismo alemão e divulgada por pensadores individualistas tais como Stirner e Nietzsche, foi revivida enfaticamente pelo período expressionista. (CARDINAL, 1984, p. 35)

A propensão do expressionismo ao subjetivismo retoma aquilo que os movimentos anteriores supracitados apresentam: o sujeito criado em cima de crises, à beira da catástrofe e a um passo do abismo. "O sombrio permeia o psicológico do personagem expressionista, da mesma forma que atua na arquitetura da cena ressaltando sua visão interior" (MURARl; PINHEIRO, 2012, p. 135). A utilização de elementos internos em expressões exteriores será a base da estética expressionista em sua relação com o cinema alemão daquele contexto, que recorrerá a uma mise-en-scène composta de temas macabros e insólitos.

\section{O DIABÓlico NA TELA ALEMÃ}

Ao adentrar no ambiente psicológico do ser humano, o expressionismo contribuiu significativamente não apenas como um fenômeno estético que é partícipe da história do cinema, mas também como um anunciador artístico que desvela o agir, o sentir e o pensar humano. 
Misticismo, magia, inquietação, o terror, o fantástico e as mais diversas forças obscuras coadunam a complexidade psíquica à uma complexidade ótica que se revela na diegese dos filmes desse período. De acordo com Cánepa, "a distorção das formas, a iluminação fantasmagórica, a temática irracionalista, a estrutura narrativa instável e o exagero da interpretação dos atores" (2010, p. 80) marcam a estética do cinema expressionista.

O projeto moderno de iluminar o homem por meio da razão é colocado em xeque na mise-en-scène deste movimento: os personagens são seres atormentados, amedrontados, perseguidos e distanciados da pretensa liberdade e autodeterminação apregoada pela ideologia do progresso.

Os cenários labirínticos, deformados e cheios de dobras formam um "espaço dramático regulado por forças distintas" (XAVIER, 2005, p. 10), que privilegiam o escuro nas bordas e o claro no centro. Desse modo, "a iluminação e seus efeitos de luz e sombra, por exemplo, não foram apenas elementos formais para adornar os cenários, mas parte fundamental do tema central do expressionismo: a luta entre a luz e a sombra como a alegoria do conflito entre a razão e o mito" (KOHATSU, 2013, p. 106).

Importante ressaltar que, embora hoje sejam considerados sob o rótulo do expressionismo, os filmes daquele período apresentam uma multiplicidade de características fruto da própria diversidade plástica do movimento. Em algumas obras, as similitudes de traços como os supracitados reúnem temáticas exploradas em torno da ordem daquilo que é trágico na existência, entre eles, os "personagens obcecados por visões e 
conflitos internos, a personalidade cindida e a presença do duplo, a submissão voluntária dos indivíduos e a manipulação da massa" (KOHATSU, 2013, p. 104).

Segundo Eisner, essas representações estavam ligadas à alma torturada da Alemanha de então, pois "tais filmes, repletos de evocações fúnebres, de horrores, de uma atmosfera de pesadelo, pareciam o reflexo de sua imagem desfigurada e agiam como uma espécie de enxutório" (1985, p. 25).

Marco inaugural da estética expressionista e que serve de referência para a cinematografia posterior, $O$ Gabinete do Dr. Caligari (1920) de Robert Wiene, desbrava, com seu poder imagético, truques ilusionistas fantásticos abordados a partir de uma natureza humana em bruma que sai do particular e vai ao universal. A angustiante visão de um espaço fantasmagórico e artificial, a mimese expressivamente exagerada, as escadas e as pontes como caminhos que levam ao abismo, além da complexidade narrativa de uma história dentro de outra, assinalam a riqueza das formas apresentadas por Wiene em Caligari.

Um sentimento de insegurança e de insólito invade o interior de cada cena. Um clima de angústia e inquietação nascido das formas cenográficas conferem um sentido trágico à passagem dos personagens. Com tal sentido plástico, o caligarismo traduz por linhas, formas e volumes, uma intencionalidade psicológica que influi e aflui ao pathos trágico perturbando as personagens. (DIAS, 2007, p. 56)

O caligarismo nasce, então, com uma estilística visual que denota o mundo das distorções como as ressonâncias do 
irracionalismo, da crítica ao método científico, das sombras e dos pesadelos dissonantes que traduzem o espirito de sua época e de todas as outras. A atmosfera de ameaça, insegurança e medo é revelada na diegese narrativa dos filmes expressionistas como um horror inominável acerca daquilo que vai além do controle do sujeito moderno na contingência da vida.

O caligarismo é a égide estética, por exemplo, de $O$ Gabinete das Figuras de Cera (1924), de Paul Leni. O exagero dos aspectos nos cenários tridimensionais e labirínticos que causam estranheza, além da atmosfera aterrorizante, embora cômica algumas vezes, tornam fantástico o enredo das histórias dentro da história que formam o filme. As formas geométricas e a aparência onírica ressaltadas em Caligari são ratificadas por Leni e auxiliam a percepção imagética da existência como ilusão, sonho ou mesmo pesadelo.

Dois outros filmes que também são referências do expressionismo no cinema alemão advêm do cineasta Paul Wegener. O Estudante de Praga (1913), por exemplo, explicita a compreensão dos alemães de que o "cinema pode se tornar o médium por excelência de sua angústia romântica, permitindo reproduzir o clima fantástico das visões vagas que se esfumam na profundidade infinita da tela, espaço irreal que escapa ao tempo" (EISNER, 1985, p. 40).

A representação do eu e seu duplo captam símbolos do cenário que traduzem a dualidade fantástica na qualidade das imagens do filme. Já em $O$ Golem (1920), o caráter irracional do monstro de barro, que não é nem bom nem mau, é apresentado 
por meio de uma fotografia contrastada com cenários artificiais e assustadores que reafirmam o uso do fantástico como traço estilístico da estética expressionista.

Na filmografia de Fritz Lang, encontramos uma "espécie de predileção - quase uma obsessão - pelas covas fantásticas no coração dos mistérios subterrâneos" (EISNER, 1985, p. 163). O realizador de A Morte Cansada (1921), Metropolis (1927), e M, O vampiro de Dusseldorf (1931) - para citar apenas algumas das expoentes películas de Lang - é famoso pela magnitude visual, pelo desequilíbrio visual e pelo jogo de iluminação que apresenta em seus filmes.

Em Metropolis, por exemplo, Lang traz uma imprecisão nas imagens construídas a partir da sensação vertiginosa dos elementos da modernidade destacados no longa. O exagerado artificialismo modernista - ao invés da distorção dos cenários - constrói a dureza da vivência numa cidade cosmopolita. Os gestos bruscos da encenação, contudo, espelham a angústia de um mundo dividido e rachado. O duplo aparece como um elemento fantástico da criação científica que põe um robô construído à imagem da líder dos trabalhadores.

Considerado por Lotte Eisner como o "maior diretor que os alemães jamais tiveram" (1985, p. 73), Friedrich Wilhelm Murnau transpassa a atmosfera do horror com o seu Nosferatu (1922). 0 filme, adaptação não-autorizada de Drácula, de Bram Stocker, segue influenciando uma geração de cineastas pelo uso das sombras, da iluminação, dos personagens insólitos.

Para Eisner, todos os filmes de Murnau traduzem a marca de uma dolorosa complexidade íntima, uma luta que se travava dentro 
dele contra um mundo "ao qual permanecia desesperadamente estranho. [...] Sua alma feroz, que carrega a pesada herança de uma sentimentalidade tipicamente alemã de uma timidez mórbida, admira no outro a força muscular e a vitalidade que lhe faltam" (1985, p. 73).

Os personagens sinistros, que parecem habitar algum recanto escondido de nosso próprio ser, interligam-se em montagens sensíveis que estilizam os cenários e povoam o vazio monstruoso que existe em nós. A subjetividade soturna que permeia o céu nublado de Fausto (1926), também de Murnau, é sinalizada como a cisão do fundamento interior do personagem que dá título ao filme também considerado referência na estética aqui estudada.

\section{APROPRIAÇÕES DA ESTÉTICA EXPRESSIONISTA}

Com a migração em massa de diretores, roteiristas, produtores e artistas alemães para os Estados Unidos a partir dos anos 1920 - parte devido à incorporação da indústria hollywoodiana desse pessoal e parte devido à ascensão do nazismo - o expressionismo parecia chegar ao fim. O acesso dos alemães ao mercado estadunidense foi realizado com restrições e limitações fílmicas: as novas películas precisariam estar adaptadas à linguagem-padrão de Hollywood, tornando possível que apenas algumas temáticas da vanguarda influenciassem as películas.

A Universal foi à principal produtora destes e obteve sucesso em muitas de suas apostas, principalmente durante as décadas de 30 e 40 . A repulsa dos personagens alemães e horror que os acentuavam se transfiguraram em ousadias temáticas dentro do cinema feito nos Estados Unidos, trabalhando 
o emocional do espectador. Além das filmografias de Tod Browning e James Whale, vale destacar dentro do ciclo de monstros da Universal Pictures: a versão espanhola de "Drácula" (Dracula, 1931), dirigida por George Melford; "O Crime da Rua Morgue" (Murders in the Rue Morgue, 1932); de Robert Florey; "A Múmia" (The Mummy, 1932), de Karl Freund; "O Gato Preto" (The Black Cat, 1934), de Edgar G. Ulmer; "O Corvo" (The Raven, 1935), de Lew Landers; "A Mão da Múmia (The Mummy's Hand, 1940), de Christy Cabanne e "O Túmulo da Múmia” (The Mummy's Tomb, 1942), de Harold Young. (MURARI; PINHEIRO, 2012, p. 140)

A partir dos anos 1940, com a irrupção do filme-noir na produção hollywoodiana, o visual contrastado e sombrio da estética expressionista "atinge o cinema americano, reconfigurando as imagens em termos estéticos. Além dessa alteração imagética, os argumentos dos filmes também mudaram" (MURARI; PINHEIRO, 2012, p. 140).

As divergências entre o noir e o expressionismo, porém, aparecem: agora há o uso do flashback; ênfase em objetos como armas e facas; realismo nas atuações; cenários e ambientes funcionais, entre outros. O próprio Fritz Lang realizou alguns filmes que dialogam com a estética noir, como em Quando desceram as trevas (1944) e O segredo atrás da porta (1948). Os dramas do período expressionista remodelaram o cinema americano e ecoam influências até os dias atuais.

Enquanto os ecos do expressionismo se modulavam no filmenoir, a Alemanha via o seu cinema mergulhar na ideologia nazista, que tinha por missão audiovisual "conquistar o mundo, tornarse a vanguarda das tropas nazistas" (EISNER, 1985, p. 228), com 
produção de filmes com tendência definida e associados ao ideal racial que acompanhava o regime totalitário. 0 expressionismo passa a ser visto como arte que degenerava os princípios e valores do Terceiro Reich.

Com a queda do regime autoritário, o movimento conhecido como Novo Cinema Alemão resgata alguns pontos da estética vanguardista. Os paradigmas artísticos do expressionismo, contudo, seguiram influenciando e remodelando a indústria do cinema. A vanguarda marcou em profundidade "o cinema alemão (Pabst, Sternberg), o cinema americano por meio da imigração (ainda Sternberg, Lang) e principalmente certos gêneros (o filme noir, Welles, Hawks, o filme de terror), o cinema europeu dos anos 1940-1950 (filmes naturalistas "noirs" de Duvivier ou Carné, por exemplo)" (GOLIOT-LÉTÉ; VANOYE, 2012, p. 32).

Películas de diretores da atualidade - como o norteamericano Tim Burton e os europeus Philipe Garrel, Leos Carax e até Lars Von Trier - apropriam-se das temáticas do horror, da melancolia, das sombras, do fantástico e do insólito para permear a atmosferas de seus enredos. Essa influência faz-se presente não apenas em filmes, mas também em tudo o que compõe o cinema contemporâneo, incluindo as narrativas de ficção seriada.

\section{O ENCONTRO DO PASSADO COM O PRESENTE: CONGRUÊNCIAS ENTRE DARK E O EXPRESSIONISMO}

Sintomas do nosso tempo (JOST, 2012), as narrativas de ficção seriada já fazem parte do cotidiano dos sujeitos (pós)modernos. É inegável a atuação desse tipo de arte na contemporaneidade, principalmente após a disseminação em larga escala dos serviços 
de streaming online. As séries - que trazem novas formas de assistir ao produto audiovisual e alargam a possibilidade de escolhas do espectador - possuem uma infinidade de formatos variados e apresentam, em seus argumentos, um conjunto de influências narrativas, literárias, filosóficas, religiosas, míticas, místicas e cinematográficas.

Primeira série em língua alemã da Netflix, um dos principais serviços de streaming do mundo ${ }^{4}$, Dark aborda um enredo cujo repertório abarca desde a mitologia grega e cristã, passando por filósofos e pensadores como Nietzsche, Schopenhauer, Pascal, Shakespeare, Goethe, Ibsen, Freud, até o misticismo e ocultismo do Caibalion, texto atribuído a Hermes Trimegisto.

O argumento complexo da narrativa aponta para a multiplicidade estilística como característica de diversos gêneros do audiovisual, inclusive do cinema alemão clássico. As influências estéticas se encontram em Dark: há elementos que permeiam o gênero gótico, romântico, barroco, ficção científica, horror, suspense, entre outros.

A paisagem da série é a pequena cidade de Winden, que vivencia o impacto do desaparecimento e da morte de crianças, em um enredo que envolve viagens no tempo, incestos, suicídios, assassinatos, sociedades secretas e apocalipses. Após o suicídio do pai e o desaparecimento do amigo, Jonas Kahnwald (Louis Hofmann), o protagonista, tenta alterar o passado por meio

4 De acordo com a 18a Pesquisa Global de Entretenimento e Mídia da PWC, em setembro de 2020 a Netflix contava com um total de 195,55 milhões de assinantes em 190 países, estando na liderança dos serviços de streamings na maioria deles, inclusive no Brasil. Disponível em: https://blog.aaainovacao.com.br/guia-streaming-globopaydisney-netflix-amazon/. Acesso em: 24 fev. 2021 
de uma passagem no tempo, um buraco negro encontrado nas cavernas da usina nuclear da cidade. Nessa viagem de luz e sombra para dentro de si, o personagem descobre um nó górdio capaz de revelar aspectos obscuros sobre as quatro principais famílias que habitam a cidade: os Kahnwald, os Nielsen, os Doppler e os Tiedemann.

$\mathrm{Na}$ análise que se segue, evidenciaremos algumas características entre a estética expressionista e Dark que podem estar entrelaçadas. De antemão, destacamos peculiaridades distintas entre os objetos: em Dark, os cenários realistas e funcionais são prevalecentes, como também a mimese naturalista das atuações.

Ao apresentarmos apenas os pontos de possíveis convergência entre os objetos de estudo aqui analisados, não pretendemos avaliar apenas aquilo que é conveniente ao que poderia ser focalizado entre a estética e a série. Buscamos, antes, compreender como alguns elementos dessa estética do século $X X$, no início da história do Cinema, pode produzir ressonâncias significativas no audiovisual contemporâneo.

\section{A ATMOSFERA SOMBRIA, A MORTE E O INSÓLITO}

O homem é uma criatura estranha. Todas as suas ações são motivadas pelo desejo. Seu caráter é forjado pela dor. Quanto mais ele tenta suprimir essa dor, reprimir esse desejo, mais ele não pode escapar da escravidão eterna dos seus sentimentos. Enquanto durar a tempestade dentro dele, não conseguirá encontrar a paz. Nem na vida, nem na morte. E assim ele fará, todos os dias, o que for necessário. A dor é o seu navio, 
o desejo é sua bússola: é só disso que o homem

é capaz. (DARK, 2019, Temporada 2, Episódio 7,0min. 14seg)

Com a escuridão sendo a marca no próprio nome da série, Dark apresenta uma atmosfera sombria que gera um clima de insegurança e melancolia. A penumbra e a iluminação em claro-escuro não está presente apenas no cenário, mas em toda a mise-en-scène. Luz e sombra, deus e diabo, bem e mal, inferno e paraíso: o embate entre a dualidade ontológica do sujeito pertence à materialidade da diegese de Dark. No segundo capítulo da segunda temporada (Figura 8), por exemplo, o eu mais velho e o eu jovem do personagem Noah, dialogam entre si e ratificam a pulverização dos valores morais, algo também presente no expressionismo. Segue o trecho:

Noah: Coincidências não existem. Cada caminho é predeterminado. Tudo acontece quando deveria acontecer. Na hora certa. No lugar certo. Como se o mundo fosse um tapete coberto por uma teia de fios infinitos. Cada um em seu lugar. Mas pouco de nós sabem para onde estamos indo. Você deu o primeiro passo. Adam ficará orgulhoso de você. Eu tive esse mesmo sentimento. Vai passar.

Noah jovem: Por que o Adam nos acolheu?

Noah: Ainda há coisas obscuras para você. Mas elas virão à luz. Pouco a pouco. Quando a hora certa chegar. Noah jovem: Como sabemos o que é certo e o que é errado? O que é bom e o que é mau?

Noah: Ouvindo nossa voz interior. Não seguindo mais ninguém além de nós mesmos. Nosso verdadeiro caráter se revela não só em nossos atos, mas no propósito deles. Eu sou você. Eu sou a sua voz. Nunca se esqueça disso. Tudo está conectado. Você. Eu. O passado e o futuro. (DARK, 2019, Temporada 2, Episódio 2, 25min. 10seg.) 
A dicotomia entre bem e mal apresenta-se como face do abismo atrelado ao próprio tempo: a força que engole a tudo e a todos e que não barganha com ninguém. ${ }^{5}$ A luta, em Dark, é sobre o controle do tempo: a manutenção, a criação ou a destruição das coisas em si na linha cronológica. A ameaça e a sensação de amedrontamento surge da ordem natural das coisas: são oriundos do horror da mais radical contingência trágica a que está submetido o universo ficcional da série. Nesse sentido, o próprio processo da temporalidade produz a revelação dos segredos obscuros dos personagens e ilumina o contraste terrível da realidade diegética.

A repetição dos eventos que ocorrem em Winden, tanto no nível micro como no macro dentro daquele contexto, parecem expor pulsões mortíferas e destrutivas que se deslocam em cena. A morte vai além do fim de algo ou alguém - mas é o reiterado recomeço de tudo o que destrói e insiste em permanecer.

Nesse sentido, Dark desvela um sujeito que não tem o controle racional completo sobre a natureza e que, mesmo o tendo parcialmente, não consegue escapar ao seu destino, já que, dentro da diegese narrativa, o tempo e a morte são ingovernáveis. A sentença de Shakespeare que aparece na abertura do oitavo capítulo da primeira temporada, por exemplo, confessa: "O inferno está vazio e todos os demônios estão aqui" (DARK, 2017, Temporada 1, Episódio 8, Omin. 10seg.). Os personagens atormentados por uma espiral de dor e sofrimento - devido a um passado ou futuro indeléveis e um presente insuportável visualizam a tempestade de seus dias como um inferno do qual não conseguem se livrar.

5 Cronos, deus do tempo, é conhecido na mitologia grega por engolir todos os seus filhos. 
A monstruosidade e a deformação do expressionismo aparecem aqui como a contorção de uma cidade que está entrelaçada em nós temporais e ciclos de angústia oriundos do próprio processo do tempo em seu percurso, do devir. ${ }^{6} \mathrm{~A}$ deformidade vai além do contexto diegético, visto que, ao apresentar uma narrativa nãolinear, Dark nos introduz às estruturas sinápticas que distorcem o nosso modo de compreensão sequenciado e contínuo.

Frente aos paradoxos e ambiguidades das coisas - que são, de algum modo, inerentes à própria vida - a penumbra se torna paulatinamente mais espessa e obscura com o passar das temporadas de Dark. Isso porque, ao adentrarmos na esfera psicológica do mundo de Jonas (Adam) - o protagonista que tenta alterar o seu passado e toda a rede incestuosa que compõe sua família - ou na atmosfera do mundo de Martha (Eva) - que tenta manter a estrutura da realidade diegética enquanto tal, sendo a antagonista de Jonas e, simultaneamente, o amor de sua vida, mãe de seu filho e sua própria tia - somos atravessados pela luz e pela sombra dispostos na mise-en-scène.

A natureza nos cenários traduz os reflexos dos estados da alma de Jonas e de Martha. A penumbra cada vez mais sombria daquilo que exprime o mais íntimo do personagem é sentida no exterior (Figuras 1, 2 e 3): a escuridão, a sequidão, a destruição, as obscuridades, 0 abandono. A tempestade dentro de Jonas parece anunciar a trovejante angústia que constitui a disjunção de seu mundo.

O futuro (Figura 1), sempre semicerrado pelo destino em um eterno devir, apresenta-se como um espectro do resultado

6 Em alemão, o verbo Winden significa enrolar, um ligar que dá volta, serpentear, enrolar uma fita em volta de algo. No reflexivo, pode significar contorcer-se. 
da busca de Jonas pelo passado de si, ou mesmo pela tentativa de destruição deste. Face ao expressionismo, que por meio de cenários angulosos e disfórmicos evidencia os traços psicológicos do sujeito, em Dark vemos a predominância de uma natureza realista que por si mesma é destrutiva e intricada em pulsões mortíferas reveladoras de um herói despedaçado pelas tragédias que vivencia, e das quais é causa e efeito.

No entanto, como nos mostram as figuras 4 e 5, as deformidades do cenário da peça Ariadne e a atmosfera acachapante de penumbra próprias do expressionismo, encontram-se nos planos em que os personagens principais demonstram as obscuridades oriundas de seus universos interiores.

Figura 1: O futuro, em 2052, como terra arrasada

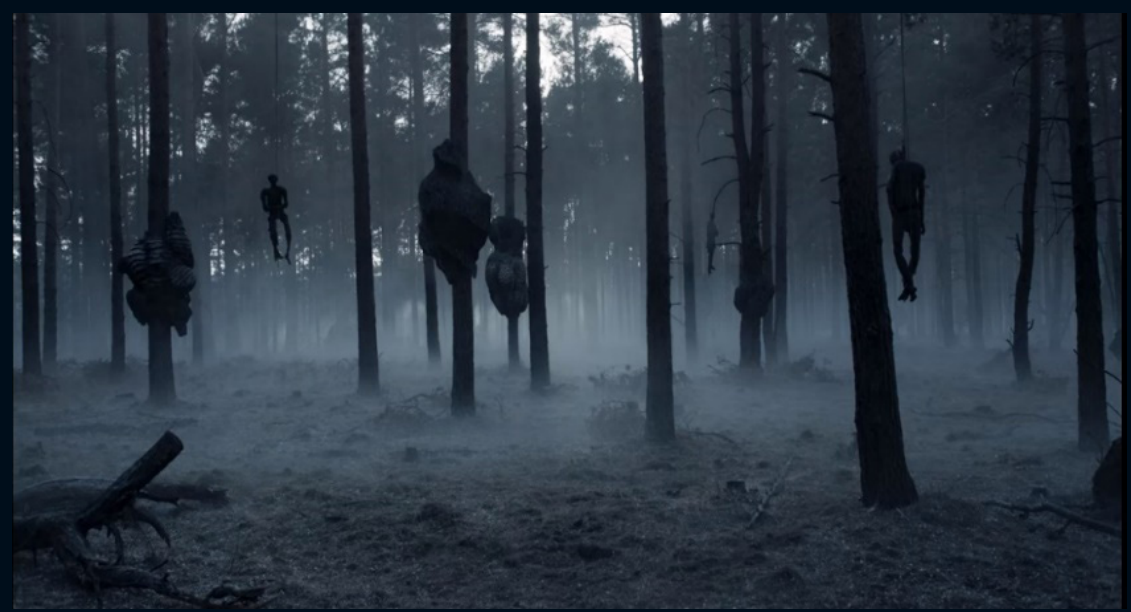

Fonte: Dark, 2019; Temporada 2, Episódio 1, 26min. 54seg. 
Figura 2: Jonas caminha entre os escombros

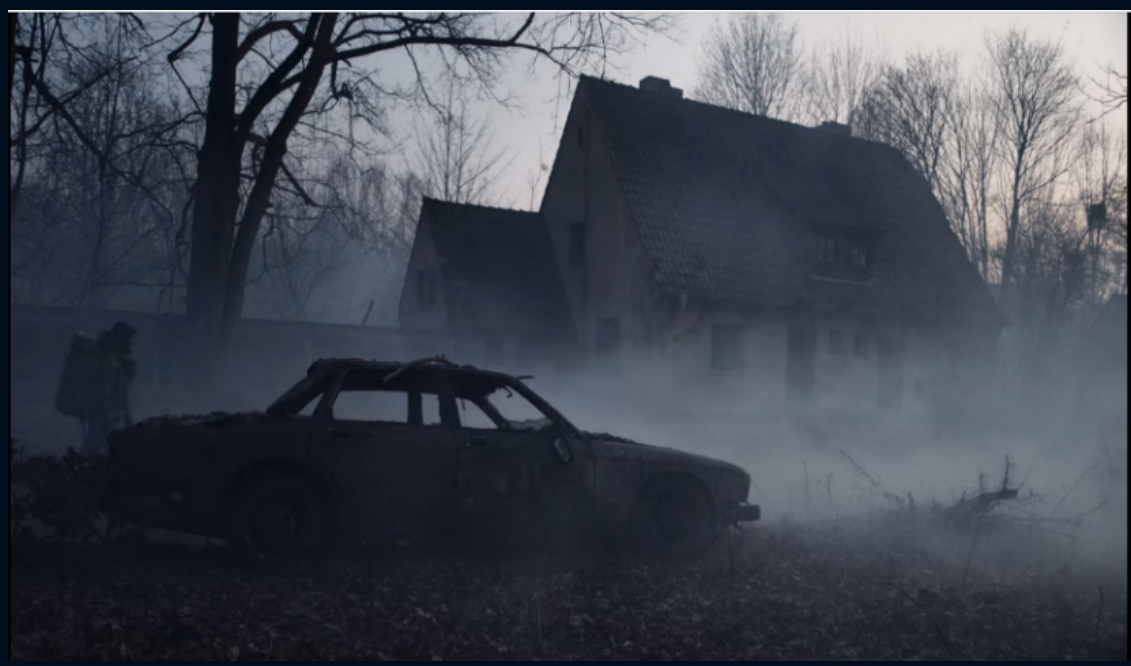

Fonte: Dark, 2019; Temporada 2, Episódio 1, 8min. 41seg.

Figura 3: Jonas entra no mundo de Martha

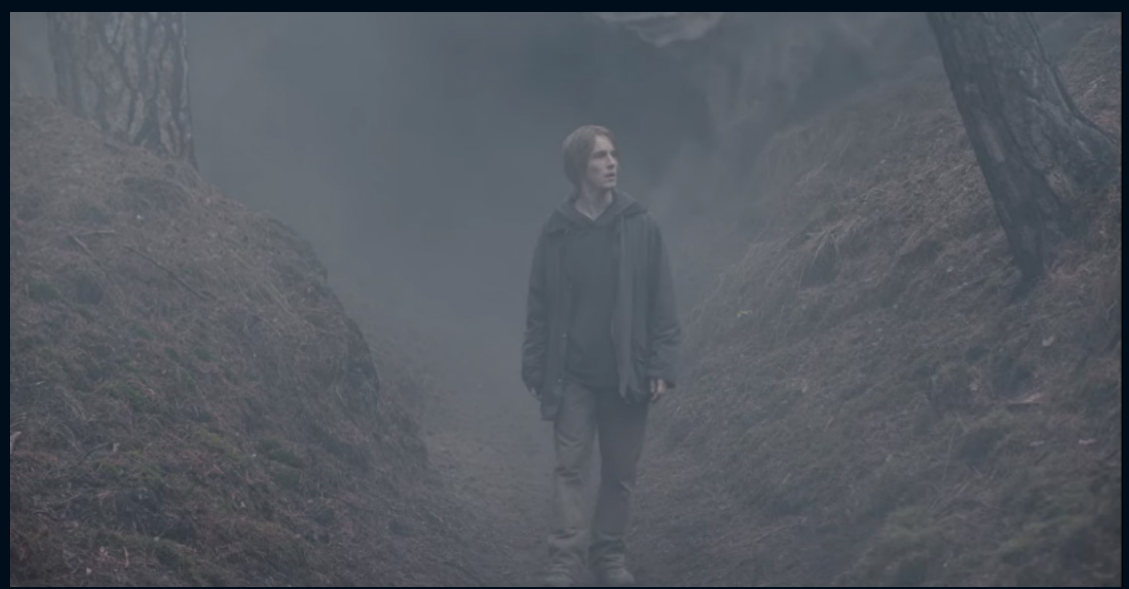

Fonte: Dark, 2020; Temporada 3, Episódio 1, 14min. 10seg. 
Figura 4: Cenário da peça Ariadne em Dark, nos remete à atmosfera do expressionismo

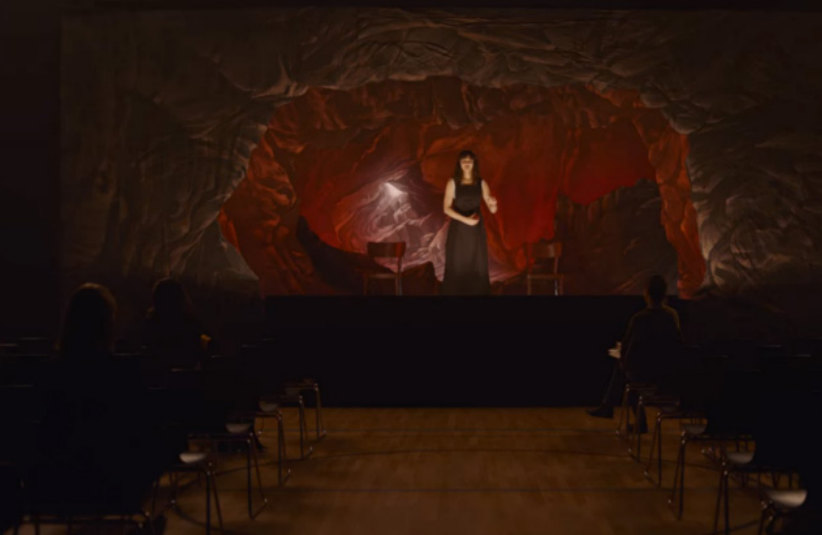

Fonte: Dark, 2020; Temporada 3, Episódio 1, 29min. 30seg.

Figura 5: A mudança da luz no cenário traduz os estados da alma de Jonas

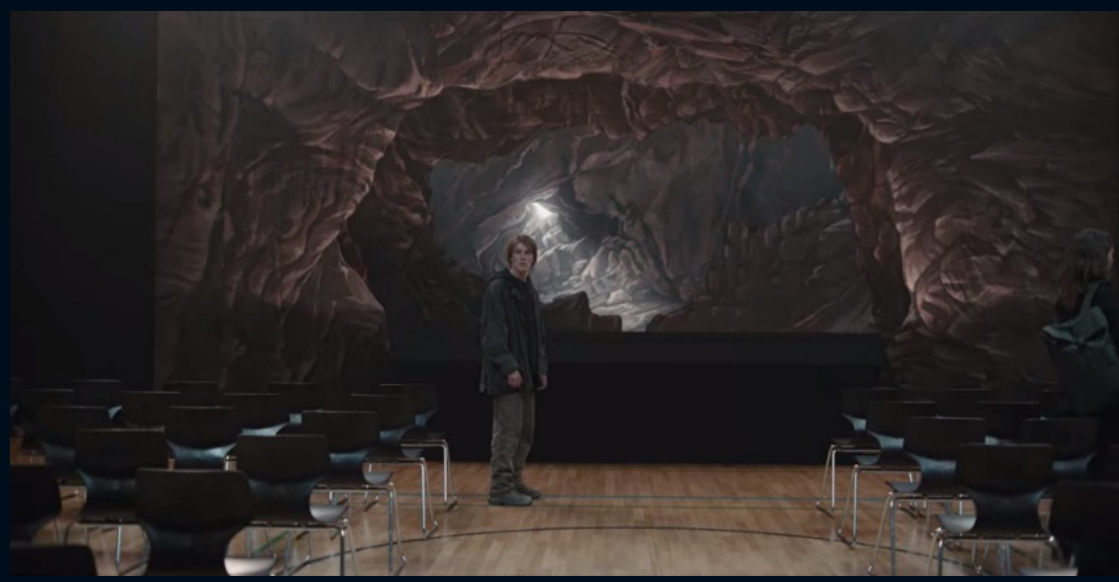

Fonte: Dark, 2020; Temporada 3, Episódio 1, 31min. 51seg.

O luto que parece mergulhar o herói nas vísceras do seu interior é, antes de tudo, um luto de si: de uma parte sua que já está morta, que foi embora junto com a morte do pai, a perda do amigo, a separação de Martha. A escuridão reina no universo 
obscuro (Figura 2) de Dark: "Somos atraídos pela escuridão assim como as mariposas são atraídas pela luz. Nascemos da escuridão e retornamos a ela" (DARK, 2020, Temporada 3, Episódio 7, 01min. 02 seg.), diz o personagem sem nome, filho da relação de Martha e Jonas, no sétimo episódio da terceira temporada. A carta deixada pelo pai do herói reitera: "[...]Fazemos de uma mentira a nossa verdade para sobreviver. Tentamos esquecer. Até não ser mais possível. Não conhecemos nem metade dos mistérios do mundo. Somos andarilhos na escuridão." (DARK, 2019, Temporada 2, Episódio 6, 49min. 40 seg).

Como viajantes carregando suas sombras, Martha e Jonas vivem um tempo infinito dentro de um período de tempo finito que se repete: aquele que acontece entre o nascimento e a morte de cada um. As micro-histórias que constituem as vidas dos personagens de Dark narram, sobretudo, de forma simbólica, as nossas próprias histórias: os erros que cometemos, os segredos que escondemos, as mentiras que fingimos, as indecisões que nos cegam, os arrependimentos que levamos, os ciclos que não fechamos, as lutas que travamos, as lembranças que não conseguimos esquecer.

O insólito, então, aparece em Dark como algo inerente à memória. As obscuridades de outros tempos, quando vêm à tona no momento em que os personagens estão, parecem incomuns. $\mathrm{O}$ efeito de estranhamento acontece, justamente, devido ao laço temporal imutável que impede os personagens de conhecerem a relação de causa e efeito do presente diegético. $O$ fantasmagórico passado gótico parece estar sempre à espreita dos personagens. 
Os eventos do passado não mais auxiliam na compreensão do que está por vir: Tornamse estranhos e potencialmente aterrorizantes, retornando, muitas vezes em figurações fantasmagóricas, para afetar as ações do presente. Em uma de suas formas de enredo mais recorrente, a protagonista da ficção gótica é vítima de atos pretéritos, nem sempre por ela perpetrados, e precisa enfrentar seu passado como condição para recuperar o controle de seu presente e a esperança em um futuro melhor. (FRANÇA, 2017, p. 2493)

Em Dark, a reiteração de práticas e hábitos transmitidos entre as gerações das famílias que compõem o núcleo do enredo, também constitui o potencial aterrorizador da trama. A ascendência e a descendência geracional continuam a repetir os erros outrora cometidos. Essa herança maldita e aparentemente atávica à diegese está exposta, por exemplo, numa conversa entre Regina e Aleksander, quando ainda jovens, em 1986, no segundo capítulo da segunda temporada.

Regina: Você acredita em fantasmas?

Aleksander: $\mathrm{O}$ que você quer dizer?

Regina: O livro que estamos lendo na escola é sobre os fantasmas e demônios que herdamos dos nossos pais e que passamos adiante. Coisas sombrias. De geração em geração.

Aleksander: Talvez... Mas você só herdou coisas boas da sua mãe.

Regina: Eu nem sabia que ela tinha coisas boas.

Aleksander: Não?

Regina: Você não faz ideia. Ela nunca está lá. Quando está, tudo o que faz é reclamar sobre mim. Ela nunca disse "Eu te amo". (DARK, 2019, Temporada 2, Episódio 2, 21min. 25 seg.) 
O livro a que Regina se refere tem o título Gengagere (Espectros, em português), do dramaturgo Henrik Ibsen. A série não detalha as especificidades da publicação, mas a ideia da transferência de traços sombrios e fantasmagóricos que atravessam o tempo em laços consanguíneos aponta para um dinamismo estático que atribui características da ascendência a subjetividades que já nascem destinadas à escuridão de seus antecessores, o que pode revelar o caráter expressionista da narrativa. Assim, a anormalidade é constituinte do enredo da série, já que, embora o curso das coisas se mostre da forma que está, a maioria dos personagens considera tudo aquilo incomum, preferindo alterar o passado ao invés de aceitá-lo, ou viver o presente.

A atmosfera onírica também entra em cena, desvelando os aspectos subjetivos e obscuros dos personagens e apresentando seus desejos mais profundos - ou medos mais intensos. Para Jung (2001, p. 24), os sonhos tem uma significação própria, mesmo quando provocados por alguma perturbação emocional em que estejam também envolvidos os complexos habituais do indivíduo. Segundo o autor, "o aspecto inconsciente de um acontecimento nos é revelado através dos sonhos, onde se manifesta não como um pensamento racional, mas como uma imagem simbólica" (JUNG, 2001, p. 20).

Em Dark, essas imagens simbólicas aparecem tanto em visões (Figura 6) quanto em sonhos (Figura 7), revelando as instâncias recônditas de Jonas, cuja desolação emocional devido às perdas sofridas reaparece como fantasma de suas angústias. Aqui também podemos estabelecer uma ponte com a atmosférica onírica do expressionismo, que propõe mostrar um humano muito mais 
próximo de suas densas emoções e irracionalidades que um ser puramente lógico ou racional.

Figura 6: Michael aparece nas visões de Jonas com uma aparência incomum

Fonte: Dark, 2017; Temporada 1, Episódio 1, 39min. 55 seg.

Figura 7: Jonas sonha que uma matéria escura sai de seus ouvidos

Fonte: Dark, 2017; Temporada 1, Episódio 2, 1min. 52 seg.

\section{A DUALIDADE DOS PERSONAGENS E SEUS EUS}

A ideia de duplo na psicanálise está ligada a uma sensação inquietante: o "segundo ser" parece despertar de uma dissociação do eu original, que já estava presente na identidade do sujeito, mas que foi esquecida ou reprimida (FREUD, 2010). Para Jung, "a psique do indivíduo está longe de ser seguramente unificada. 
Ao contrário, ameaça fragmentar-se muito facilmente sob o assalto de emoções incontidas" (2001, p. 21). Já na literatura, influenciada pela psicanálise e filosofia, a duplicação do eu está associada à consciência moral do indivíduo ou como reflexo de sua parte instintiva, que Ihe aparece como estranha, mas que lhe é constitutiva.

Em produtos de ficção científica, o duplo "é criado a partir de procedimentos tecnológicos ou científicos. Isto quer dizer que, na maioria dos casos, a construção do duplo na ficção científica é justificada por esses procedimentos" (SASSE e MOURA, 2020, p. 178). No mundo ambíguo do cinema alemão, onde "ninguém está seguro de sua identidade, e além disso pode muito bem perdê-la no caminho" (EISNER, 1985, p. 80) o desdobramento demoníaco aparece em muitos filmes:

Caligari é ao mesmo tempo o eminente médicochefe e o charlatão de feira. Nosferatu, o vampiro, dono de um castelo feudal, quer comprar uma casa de um corretor de imóveis, este também imbuído de diabolismo. E a personagem da Morte, em A Morte Cansada, é ao mesmo tempo um simples viajante à procura de um terreno à venda. Parece que para o alemão o lado demoníaco de um indivíduo comporta forçosamente um contraponto burguês. (EISNER, 1985, p. 80)

Em Dark, as ambivalências dos personagens são expostas deliberadamente. Com o desaparecimento de Mikkel Nielsen, um dos personagens centrais na narrativa, a mãe do garoto, Katharina Nielsen, em um programa de rádio, escancara as obscuridades e possíveis segredos dos moradores de Winden. O fato está presente no sexto capítulo da primeira temporada. 
Achamos que sabemos tudo sobre o outro. Mas será verdade? Somos vizinhos de pessoas cujas vidas não sabemos nada. E por trás de uma dessas portas está meu filho. Pode ser qualquer uma. A do caixa do mercado. Ou um convidado de domingo, que brinca com nossos filhos. Não quero mais fechar os olhos. E vocês deveriam fazer o mesmo. Esta cidade está doente. Winden é como um câncer. E todos fazemos parte disso. (DARK, 2017, Temporada 1, Episódio 6, 24min. 44 seg.)

A possível vida dupla dos moradores da cidade, questionada por Katharina é, na verdade, característica de boa parte dos envolvidos na trama. O desvelamento da história dos personagens e a justificativa sobre cada ato aparentemente maligno vão sendo desmontados com o passar das temporadas. Noah, por exemplo, na primeira temporada aparece como um reverendo bondoso, mas é o responsável pela morte das crianças e luta pela destruição de Winden.

Nas duas temporadas seguintes, descobre-se que ele estava sendo manipulado por Adam para que, ao fazer o que este pedia, pudesse manter o ciclo e obter sua filha (Charlotte) e esposa (Elizabeth) de volta. O próprio Adam, que na segunda temporada aparece como o vilão e o duplo de Jonas (ou o seu eu mais velho), está sendo manipulado por Eva, também para que o ciclo se mantenha e ela tenha seu filho. Claudia, a ex-chefe da usina, manipula Adam, Jonas, Eva e Martha para a destruição dos dois mundos - o que é revelado ao espectador apenas nos capítulos finais da última temporada.

Todos os acontecimentos, até aqueles aparentemente acidentais (como no caso da explosão do sistema de volume 
de controle da usina) estão sujeitos à manipulação de uma alteridade, seja Eva, Martha, o Estrangeiro (Jonas de meia-idade), Adam, Noah ou Claudia. Jonas, o herói, também está submetido à manipulação. O trecho abaixo é um dos momentos em que Jonas descobre o controle de Eva sobre a situação vivenciada junto com Martha:

Jonas: O arranhão. Ela também tinha, a Martha que me trouxe para cá. Tudo se repete. Ela queria mudar isso. Mas, se você se tornar ela, tudo ficará igual. Por que a Eva mentiu? Ela disse que há um jeito de salvá-lo: o meu mundo.

Martha: Eu não sei sobre o seu mundo, mas este aqui é o meu. Se eu puder evitar que abram os barris, se puder parar tudo...

Jonas: E se for isso o que ela quer? Que aconteça tudo de novo? Talvez ela não queira que evitemos. Pode ser que nós sejamos a causa.

Martha: Por que ela iria querer isso?

Jonas: Porque todos eles mentem! O tempo todo eu fiz o que os outros disseram. Não importa o que eu faça, tudo só fica pior. Eu tenho que voltar para a Eva. Eu finalmente quero saber a verdade. (DARK, 2020, Temporada 3, Episódio 5, 23 min. 10 seg.)

O desamparo do humano, que é da nossa estrutura psíquica e, consequentemente, a ligação com uma alteridade que sempre sabe mais do que nós, coloca os personagens a mercê do outro ou do seu eu mais velho. Para o filósofo Lutz Müller (2017), a cisão entre o eu jovem e um eu maduro está associada a estruturas psíquicas formadas na infância.

Essa duplicidade de sua primeira situação de vida corresponde à duplicidade do seu caráter: ora ele é o herói luminoso, radiante, amigável, defendendo 
a conservação e o desenvolvimento de estados vitais positivos; ora ele é capaz de se tornar uma pessoa calculista, colérica, egoísta, sedenta de poder, violenta e pronta para se enfurecer de maneira cruel e sádica por uma "boa" causa, tal como as forças inimigas que ele se propôs superar. (MÜLLER, 2017, p. 84)

O encontro dos personagens com o eu mais velho acontece, na maioria das vezes, de forma bastante traumática (Figuras 9 e 10) em Dark. A visualização do futuro eu no presente diegético e a demolição de uma idealização acerca do ulterior choca os personagens por terem que cumprir o - nem sempre aprazível destino que levará à sobrevivência e manutenção de suas vidas, mesmo que dilaceradas.

Figura 8: O eu mais velho e mais jovem de Noah

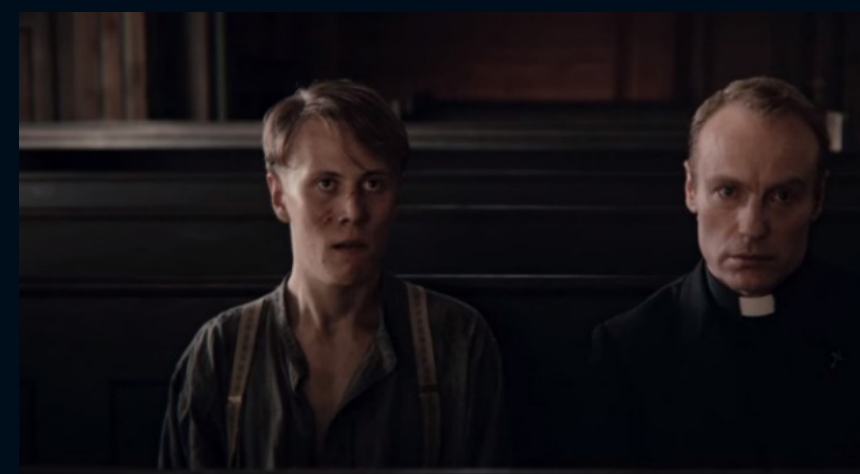

Fonte: Dark, 2019; Temporada 2, Episódio 1, 25min. 10 seg. 
Figura 9: O encontro dos eus de Claudia

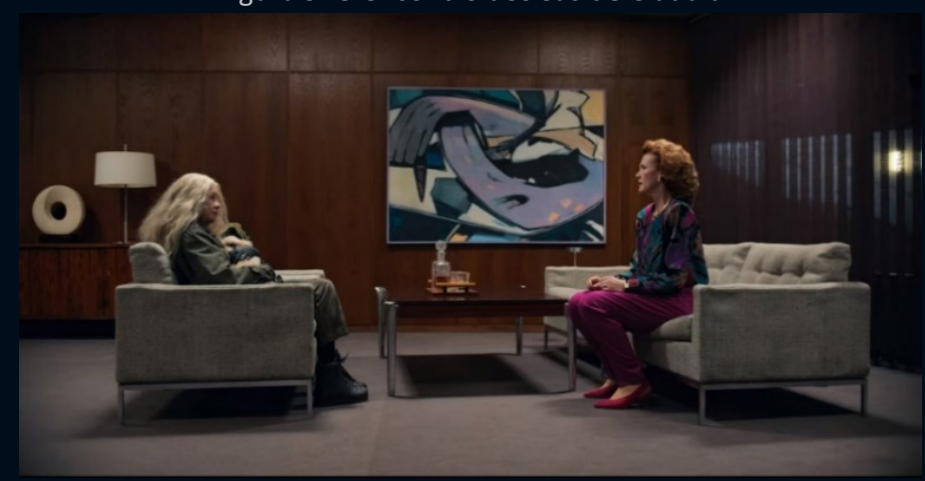

Fonte: Dark, 2019; Temporada 2, Episódio 2, 16min. 23 seg.

Figura 10: Jonas encontra ao seu eu mais velho, Adam

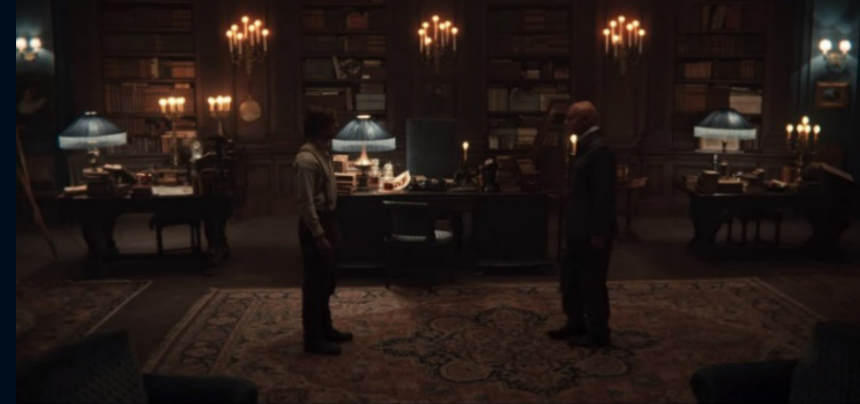

Fonte: Dark, 2019; Temporada 2, Episódio 4, 55min. 15 seg.

Figura 11: Claudia encontra o seu eu de mesma idade oriundo da realidade paralela e a mata.

Fonte: Dark, 2020; Temporada 3, Episódio 7, 30min. 03 seg. 
Figura 12: Cena de O Estudante de Praga (1913) ${ }^{7}$

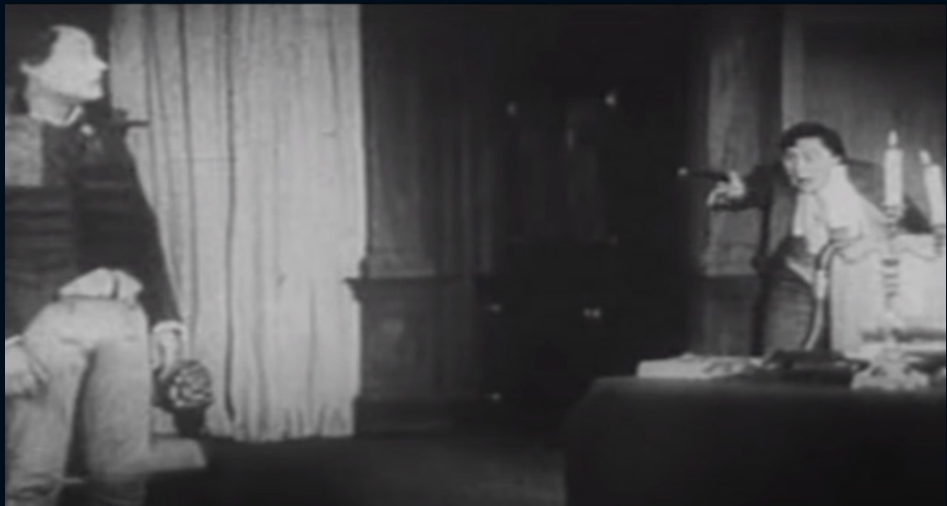

Fonte: O Estudante de Praga, 1913, 53min. 12 seg. Disponível em: shorturl.at/fjzE2 Acesso em: 02 mar. 2021.

Como já mencionamos, vários filmes expressionistas trouxeram a temática do duplo em seus enredos. O exemplo supracitado (Figura 12) é um dos que podem ter influenciado Dark (Figura 11). Outro filme é a película $A$ cabeça de Janus (Der Januskopf), produzida em 1920 sob a direção de F. W. Murnau. O horror do protagonista, cuja dupla personalidade é marcante, pode ter sido uma das influências mais diretas da obra de Murnau em Dark.

Além do nome dos protagonistas serem semelhantes (Janus e Jonas), a mitologia romana compreendia o deus Janus como o representante dos términos e dos começos, do futuro e do passado, das transições (AGOSTINHO, 2019). Janus era considerado o deus das duas faces: a que acalenta, guia, protege e ama; e aquela que engana, trai, odeia e trapaceia.

7 A cena de $O$ Estudante de Praga, produzido por Paul Wegener, se assemelha à da figura (11) anterior. O longa expressionista é uma adaptação do livro homônimo de Edgar Allan Poe, notável pela literatura de horror. 
Nesse sentido, um dos plot-twists mais notáveis da série é justamente o encontro entre Jonas e o seu eu mais velho, Adam (Figura 10). "Não é estranho sentirmos a maior aversão às pessoas que são mais parecidas conosco?" (DARK, 2019, Temporada 2, Episódio 5, 3min. 08 seg.), questiona Adam à reação repugnante de Jonas sobre o seu futuro eu e todo o rastro de destruição deixado por ambos. "Se o herói de um filme pode agir de forma tão excessiva, a ponto de querer aniquilar uma imagem, então, em consequência, o espectador deve se sentir igualmente eletrizado" (CARDINAL, 1984, p. 94).

Ao perceber-se capaz de irracionalidades e monstruosidades que serão partícipes de sua vida futura, Jonas tenta negar o seu destino e fazer o possível para que o seu futuro eu não exista: a cada passo que dava, porém, o encontro com o abismo só lhe deixava mais perto de quem se tornaria naquela realidade específica. Como escapar? Como fugir de si? Ao que parecia não haver saída, Dark apresenta, em sua última temporada, um outro mundo possível.

\section{A REALIDADE ESPELHADA, O FANTÁSTICO E A CIÊNCIA MÁGICA}

$\mathrm{Na}$ terceira temporada, o espectador entra em uma realidade diegética paralela: o espelho do universo de Jonas e Adam, o mundo de Martha e Eva. Mas, "um espelho é sempre um espelho?" questiona a estudiosa do cinema alemão Lotte H. Eisner (1985, p. 94), que continua:

A vida não passa de uma espécie de espelho côncavo que projeta personagens inconsistentes, que flutuam como as imagens de uma lanterna mágica, nítidas quando pequenas e cada vez mais esfumadas conforme crescem. "Em algum lugar 
de um mundo mais claro deve existir a lanterna mágica em cujas plaquetas estão pintados países, primaveras, grupos humanos", diz Jean Paul. O que chamamos um país, uma vida, não seriam as sombras que emanam dessas plaquetas vaporosas e saltitantes? (EISNER, 1985, p. 94)

Os truques de espelhos no cinema expressionista "são semelhantes ao uso de papéis duplos para o mesmo ator" (CARDINAL, 1984, p. 94) e reiteram o jogo visual para alimentar a ideia da realidade como ilusão.

Do outro lado do espelho, os alemães, levados por seus pensamentos metafísicos, vão bem mais fundo que Alice, pequena inglesa na realidade muito materialista, e certamente muito mais longe que Cocteau. A rima de Schein (aparência) com Sein (ser) os leva a jogar, como Ludwing Tieck, "com a realidade como com os sonhos, até o momento em que as formas nascidas das trevas pareçam as únicas verdadeiras. (EISNER, 1985, p. 94)

Em se tratando de Dark, a realidade espelhada de ambos os mundos é, de fato, uma ilusão, visto que a diegese narrativa aponta para a criação de um mundo cindido a partir de um experimento científico falho em seu intento no mundo original. As ideias de que tanto Jonas como Martha e seus futuros eus são falhas na matrix, e de que o mundo é uma simulação aparecem por diversas vezes na série.

Como, por exemplo, no primeiro episódio da primeira temporada, quando o casal conversa sobre um possível déjà$v u$ e acabam por chegar à conclusão de que isso ocorre por uma erro na base original, já que o universo apresenta-se como uma 
representação. Essa conversa se repetirá no quinto capítulo da segunda temporada e no segundo capítulo da terceira temporada, quando Jonas está no mundo paralelo ao seu, o mundo de Martha.

Os protagonistas, em seus mundos, vivem situações muito semelhantes embora estejam em realidades distintas (Figuras 13 e 14). A mise-en-scène repete-se, só que de maneira inversa: do polo masculino ao feminino. $\mathrm{O}$ espectador assiste duas vezes à repetição dos ciclos, porém, cada realidade paralela possui as suas especificidades.

Figura 13: O mundo de Martha e o mundo de Jonas

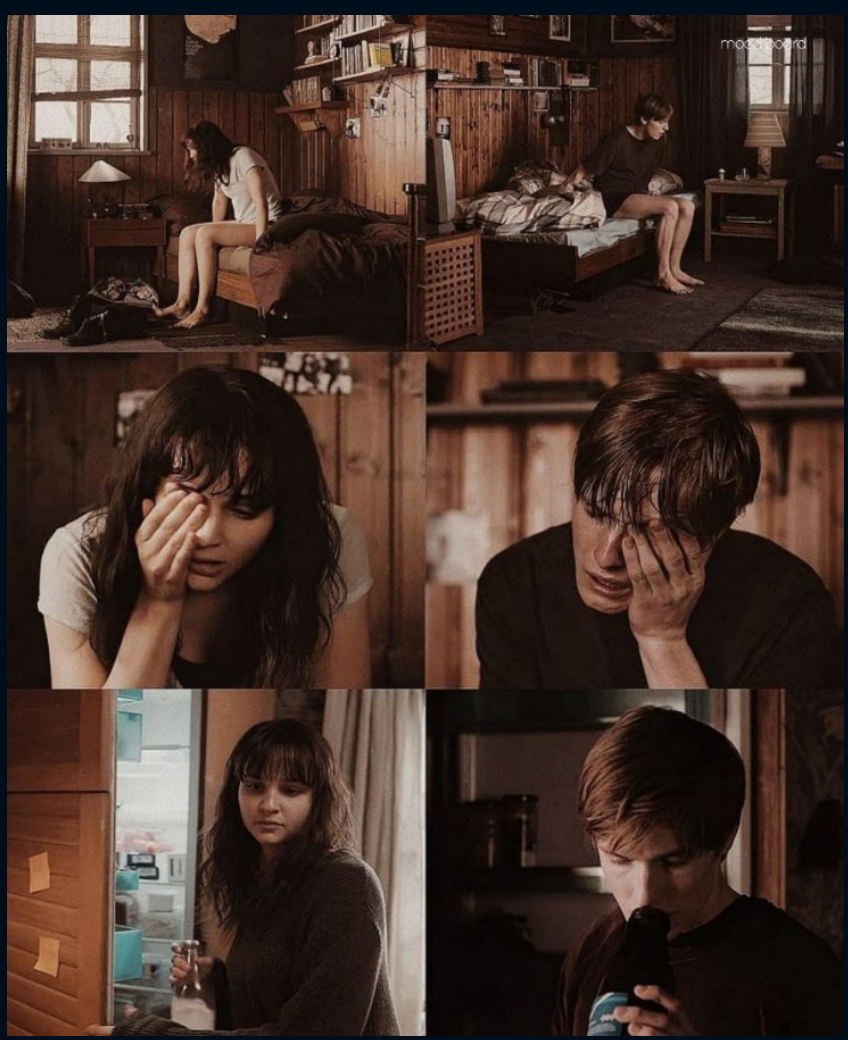

Fonte: Dark, 2020, 2017; Temporadas 3 e 1, respectivamente. 
Figura 14: A realidade espelhada nos mundos dos heróis

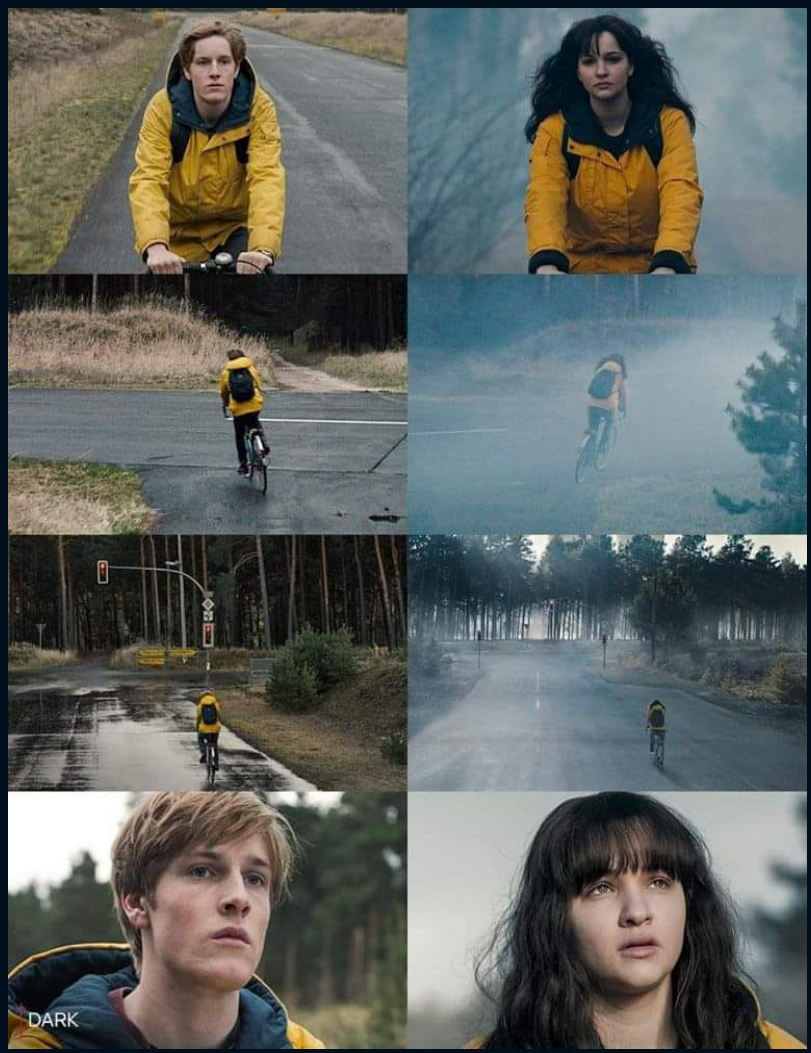

Fonte: Dark, 2017,2020; Temporadas 1 e 3, respectivamente.

O mundo-espelho duplica e acentua as imagens que o espectador vê, mas também reflete o jogo de luz e sombras consequentes de cada realidade diegética, já que uma atua em embate com a outra. O jogo dos espelhos parece traduzir a miragem dos pensamentos dos personagens.

O fato de ambos os mundos terem como origem uma realidade em que os protagonistas inexistem - bem como o universo simbólico-imaginário construído ao longo das temporadas pelo 
enredo - apresenta a arte da ciência mágica. Podemos dizer que, aqui, prevalece a arte fantástica: aquela que é capaz de acarretar "um estado de suspense incrédulo, de modo a dar a eventos paranormais o status de realidade" (CARDINAL, 1984, p. 94). Para Cardinal:

Em termos de diversão, isso significa que a plateia pode se sentir temporariamente aliviada das tensões do dia-a-dia, mas, num nível mais profundo, a apresentação de uma transformação traiçoeira, a manipulação de fé, o revestir das aparências normais de uma aura de sobrenatural, pode ser interpretado como uma tentativa expressionista de introduzir a plateia a sensações de ansiedade e vertigem, chamando atenção para as limitações da percepção ortodoxa. (CARDINAL, 1984, p. 94)

Embora o universo fantástico não tenha sido inaugurado pelo cinema expressionista alemão, este o usou de forma exaustiva, influenciando inúmeras gerações de cineastas. Segundo Tzvetan Todorov (1992), se entende por fantástico tudo aquilo que põe em dúvida a noção de real de determinado fenômeno, isto é, quando não se consegue argumentos lógicos que o justifiquem. Para o crítico literário, qualquer fenômeno pode ser explicado de duas formas "por meio de causas de tipo natural e sobrenatural. A possibilidade de se hesitar entre os dois criou o efeito fantástico" (TODOROV, 1992, p. 16). 
Figura 15: H.G.Tannhaus traz elementos científicos ao enredo

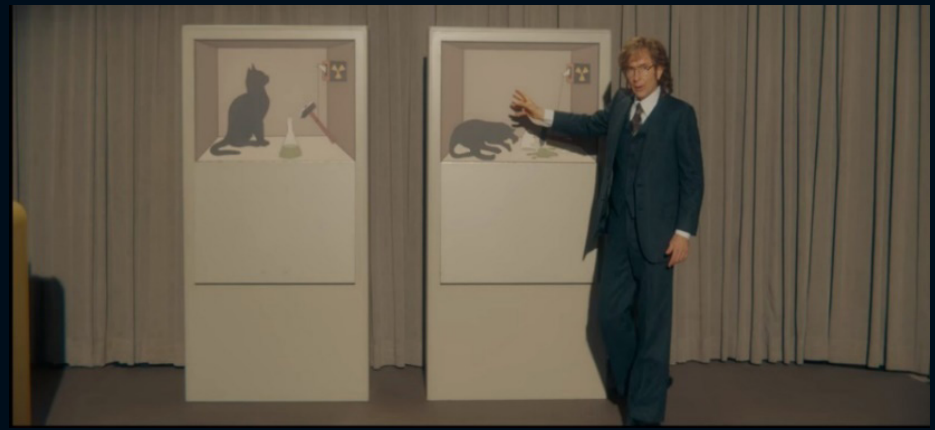

Fonte: Dark, 2020, Temporada 3, Episódio 7, 1min. 37 seg.

Em Dark, a ciência, os mitos, o ocultismo e a filosofia formam um caldeirão mágico que busca não explicar, mas levantar inúmeras questões sobre a existência e as subjetividades no seio da temporalidade. "Será que um dia conseguiremos viajar no tempo e ver o que há além? E qual preço pagaríamos por isso? Até onde iriam os cientistas?" (DARK, 2017, Temporada 1, Episódio 2, 22 min. 24 seg.). Dark questiona a partir de pressupostos científicos - ainda em experimentação - acerca do que seria o real e qual a nossa relação com ele. Segue trecho do personagem H.G. Tannhaus (Figura 15), no sétimo capítulo da terceira temporada:

O que é realidade? Só tem uma dela? Ou coexistem várias realidades? Para ajudar a explicar, Erwin Schroedinger idealizou uma experiência mental extremamente interessante: ogato deSchroedinger. Um gato está trancado em uma câmera de aço com uma pequena quantidade de substância radioativa, contador Geiger, frasco de veneno e martelo. Logo que um átomo radioativo se desintegra dentro da câmera de aço, o contador Geiger liberta o martelo, que quebra o frasco de veneno. O gato está morto. No entanto, devido às características de onda no 
mundo quântico, o átomo avariou e não avariou, até que a nossa própria observação o força para um estado definitivo. Até ao instante que olhamos e vemos, não sabemos se o gato está vivo ou morto. Existe em dois estados sobrepostos. As propriedades "morto" e "vivo", portanto existem simultaneamente no microcosmos. (DARK, 2020, Temporada 3, Episódio 7, 0min. 12 seg.)

A existência ou coexistência de realidades paralelas, buracos negros e buracos de minhoca aparecem fantasticamente, em Dark, como fatos cientificamente comprovados e possíveis de serem realizados. Essa ciência mágica, que na diegese narrativa é a responsável pela criação dos dois mundos, é a mesma utilizada para a sua destruição: a salvação do bem coletivo do mundo original vem por meio do aniquilamento dos heróis.

Na tentativa de romper e quebrar os ciclos, Jonas e Martha se unem para impedir que o trágico acidente do filho de H.G. Tannhaus ocorra e este gere a criação dos dois mundos em declínio pelo ciclo de feridas, tragédias e relações incestuosas.

A trágica sina romântica de que o amor não se concretiza e é sempre impossível vem à tona: "Eu me pergunto se sobrará algo de nós ou se é isso o que somos: um sonho" (DARK, 2020, Temporada 3, Episódio 8, 1h. 0 min. 17 seg.). Este é o último enunciado de Martha que, ao lado de Jonas no mundo original, vê a si, ao seu amor e ao mundo de ambos obliterarem-se em poeira de estrelas.

\section{CONSIDERAÇÕES FINAIS}

Como pudemos observar, os espectros do vanguardismo expressionista seguem influenciando as narrativas fílmicas alemãs 
e moldam-se ao cinema contemporâneo afluindo em tramas como a série aqui estudada. Elementos como o duplo, a manipulação, o insólito, o horror, a realidade espelhada, o fantástico e a ciência mágica aparecem na série e produzem uma trama cuja complexidade narrativa referencia aspectos relacionados também a outros estilos.

Sabemos que um gênero, num dado momento de sua evolução, "se define tanto pelo que dele é excluído quanto pelo que dele é parte integrante - o espectador usufrui, desse modo, do prazer do reconhecimento" (GOLIOT-LÉTÉ, VANOYE, 2012, p.25). Nesse sentido, entendemos que as formas cinematográficas constituemse num fundo cultural no qual os cineastas se inspiram, e portanto "cabe ao analista explicar os movimentos que dele decorrem" (GOLIOT-LÉTÉ, VANOYE, 2012, p.34).

Dark não é uma série expressionista, visto que o movimento é datado historicamente, mas toma diversos elementos da vanguarda em seu enredo. Desta forma, embora não encontremos em Dark todos as configurações expressionistas tais como os cenários disfórmicos e angulosos (em Dark, são prevalecentes os cenários realistas e funcionais; os disfórmicos apenas aparecem em poucos momentos e pertencentes a uma espécie de metalinguagem fílmica de um cenário dentro de outro, conforme figuras 4 e 5), ou a mimese exageradamente expressiva (em Dark, prevalece o naturalismo das atuações), entendemos que isso não exclui os possíveis ecos do expressionismo na narrativa.

As heranças do expressionismo em Dark, conforme verificamos, parecem trazer justamente aquilo que o movimento do século $X X$ expunha em seus filmes: a visão do mais profundo abismo, da 
dissolução e degeneração de um mundo que, em algum momento foi algo de apolíneo, racional e iluminado. Nesse sentido, a série parece desvelar, tal qual a corrente vanguardista, aquilo que a vida é em seu mais profundo grito: criação e destruição. O fim, a morte, a repetição, o horror talvez não sejam da ordem do aprazível, mas sem eles, é impossível o gestar de um renascimento que floresce na penumbra de cada crepúsculo.

Talvez a angústia da escuridão e das sombras revele os fantasmas da dupla - ou tripla - face de quem somos. Quem olha para a mais dura e terrível visão do real, para o pensamento mais abismal, mas apesar disso não encontra nesse fado qualquer objeção à existência, "nem mesmo contra seu eterno retorno - mas vê nele, muito antes, um motivo para ser, ele mesmo, o sim eterno de todas as coisas, 'o monstruoso e ilimitado dizer-sim e amém'" (NIETZSCHE, 2003, p. 122) parece ter encontrado um antídoto para o horror: o próprio horror.

\section{REFERÊNCIAS}

AGOSTINHO, Santo Bispo de Hipona. A cidade de Deus: contra os pagões, parte I. Petrópolis: Vozes, 2019.

CÁNEPA, Laura. Em torno das definições do expressionismo: o gênero fantástico em filmes da República de Weimar. Revista Galáxia, São Paulo, n. 19, p. 78-89, jul., 2010.

CARDINAL, Roger, O expressionismo. Rio de Janeiro: Jorge Zahar Editor, 1984. DARK. (Temporadas 1, 2, 3). Direção: Baran bo Odar; Jantje Friese. Alemanha; Estados Unidos: Netflix, 2017-2020.

DIAS, Fernando Paulo Rosa. O expressionismo no cinema. In: TAVARES, Cristina Azevedo; DIAS, Fernando Paulo Rosa. As artes visuais e as outras artes: as primeiras vanguardas. Lisboa: Faculdade de Belas Artes, Universidade de Lisboa. 2007. 
ECKERMANN, J. P. Conversas com Goethe. 1827. In: EISNER, Lotte H. A tela demoníaca: as influências de Max Reinhardt e do expressionismo. Rio de Janeiro: Paz e Terra, 1985.

EISNER, Lotte H. A tela demoníaca: as influências de Max Reinhardt e do expressionismo. Rio de Janeiro: Paz e Terra, 1985.

FRANÇA, Júlio. O gótico e a presença fantasmagórica do passado. In: Anais eletrônicos do XV encontro do ABRALIC - Associação Brasileira de Literatura Comparada. Rio de Janeiro: UERJ, p. 2492-2502, 2017. Disponível em: https:// abralic.org.br/anais/?ano=2017. Acesso em: 8 nov. 2020.

FREUD, Sigmund. O mal-estar na civilização. Edição Standard Brasileira das Obras Completas de Sigmund Freud, vol. XXI. Rio de Janeiro: Imago, 1996.

FREUD, Sigmund. O inquietante. In: FREUD, Sigmund. Obras completas, vol. 14: História de uma neurose infantil ("O homem dos lobos"), Além do princípio do prazer e outros textos (1917-1920). São Paulo: Companhia das Letras, 2010.

FREUD, Sigmund. Luto e melancolia. São Paulo: Cosac Naify, 2011.

GOLIOT-LÉTÉ, Anne; VANOYE, Francis. Ensaio sobre análise fílmica. Tradução de Marina Appenzeller. Campinas, SP: Papirus, 2012.

JOST, François. Do que as séries americanas são sintoma. Porto Alegre: Sulina, 2012.

JUNG, Carl Gustav. O homem e seus símbolos. Rio de Janeiro, Editora Nova Fronteira, 2001.

KOHATSU, Lineu Norio. Cinema expressionista alemão: o estranho, o estranhamento e o efeito de estranhamento. Impulso. Piracicaba, v. 23, n. 57, p. 103-118, maio/set. 2013.

MÜLLER, Lutz. O herói: a verdadeira jornada do herói e o caminho da individuação. São Paulo: Editora Cultrix, 2017.

MURARI, Lucas de Castro; Fábio Francener PINHEIRO. O expressionismo alemão e suas múltiplas devirações americanas. O Mosaico: R. Pesq. Artes. Curitiba, n. 7, p. 132-144, jan./jun., 2012.

NIETZSCHE, Friedrich. A gaia ciência. São Paulo: Escala, 2013.

NIETZSCHE, Friedrich. Ecce homo. Porto Alegre: L\&PM, 2003. 
PAREDES, Lenin Vladimir. El eterno retorno: análisis de la concepción temporal en la serie Dark de Netflix. PAAKAT: Revista de tecnologia y sociedade, v. 9 n. 16. Guadalajara. mar., 2019.

SASSE, Pedro. MOURA, Victoria Barros. O gótico e a figura do duplo em "USS Calister". Revista Abusões, Rio de Janeiro, n. 12, v. 12, ano 06, p. 172-194, 2020. Disponível em: https://www.e-publicacoes.uerj.br/index.php/abusoes/article/ view/47826/34149. Acesso em: 10 nov. 2020.

RIBEIRO, Léo Gilson. Cronistas do absurdo: Kafka, Büchner, Brecht, Ionesco. Rio de Janeiro: José Álvaro Editor, 1964.

SCHOPENHAUER. Arthur. O mundo como vontade e representação. São Paulo: Contraponto. 2001.

TODOROV, Tzvetan. Introdução à literatura fantástica. São Paulo: Perspectiva, 1992.

VALENZUELA, Sandra Trabucco. A fragmentação na série Dark: o ser, o espaço e o tempo. In: SILVA, Lourdes Ana Pereira; GUARANHA, Manoel Francisco; BASEIO, Maria Auxiliadora (Org.). Identidades ficcionais: narrativas literárias e televisivas. Covilhã: LabCom Comunicação \& Artes, p. 149-166, 2020.

VARGAS, Herom; CORRÊA, Angela Miguel. Recapitulações na série original Netflix Dark: alterações na estrutura narrativa tradicional televisual. Revista lationoamericana de la comunicación, v. 17, p. 246-257, 2019.

XAVIER, Ismail. A opacidade e a transparência. São Paulo: Paulo: Paz e Terra, 2005. 